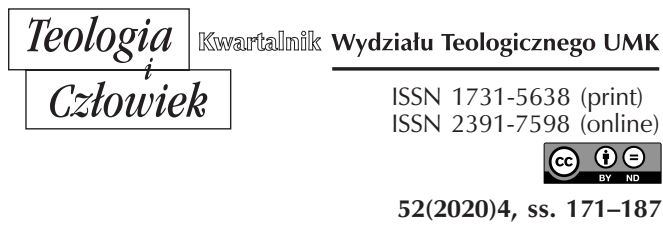

TOMASZ RÓŻAŃSKI

\title{
PRZEMOC WOBEC LUDZI STARSZYCH W RODZINIE. ZARYS PROBLEMATYKI
}

DOI: http://dx.doi.org/10.12775/TiCz.2020.057

Streszczenie. Niniejszy artykuł poświęcono problematyce przemocy wobec ludzi starych w rodzinie. Punktem wyjścia podjętych rozważań było omówienie roli i miejsca seniorów w rodzinie jako naturalnym środowisku ich życia. Następnie zwrócono uwagę na problem przemocy domowej - określono jej istotę, główne objawy i konsekwencje. W dalszej kolejności podjęto zagadnienie przemocy wobec osób starszych w rodzinie oraz poruszono wybrane kwestie dotyczące jej profilaktyki.

Słowa kluczowe: przemoc domowa; rodzina; senior.

Abstract. Violence against Older People in the Family. Outline of Issues. This article is devoted to the issue of violence against older people in the family. The starting point for these considerations was to describe the role and place of seniors in the family as their natural life environment. Then attention was paid to the problem of domestic violence - its essence, main symptoms and consequences. Next, the issue of violence against older people in the family was raised and selected issues related to its prevention were discussed.

Keywords: domestic violence; family; senior. 


\section{WSTĘP}

Rodzina stanowi zasadniczą grupę społeczną, jaka istnieje od najdawniejszych czasów. Jest ona jedyną grupą rozrodczą oraz najistotniejszą instytucją odpowiedzialną za przekaz podstawowego dziedzictwa kultury $^{1}$. Oddziałuje „na osobowość, na funkcjonowanie jednostek, a także w dużym stopniu kształtuje ich losy"2. Rodzina to naturalne środowisko życia dla wszystkich jej członków, również dla osób starszych. Co więcej, $\mathrm{w}$ wieku senioralnym często zwiększa się jej znaczenie. Stanowi to m.in. rezultat wycofywania się ludzi starych z szerszych kręgów społecznych. Tym samym rodzina staje się dla nich głównym środowiskiem życia i aktywności ${ }^{3}$, nierzadko ważnym źródłem wsparcia w różnych sferach ${ }^{4}$. Rodzina może dostarczać osobom starszym także wielu problemów. Związane są one w dużej mierze z przemianami, jakie dokonują się w obrębie współczesnej rodziny, np. mogą dotyczyć jej struktury, modelu życia rodzinnego czy relacji między pokoleniami ${ }^{5}$.

Istotnym problemem, na jaki w ostatnich latach wskazuje wielu badaczy, jest przemoc wobec seniorów w rodzinach ${ }^{6}$. Zagadnieniu temu poświęcono niniejsze opracowanie. Zwrócono w nim uwagę na następujące kwestie: rola i miejsce osób starszych w rodzinie; problem przemocy

${ }^{1}$ F. Adamski, Rodzina, w: Wychowanie do życia w rodzinie. Słownik pojęć, red. K. Ostrowska, Kraków 2004, s. 104.

2 B. Hołyst, Zagrożenia ładu społecznego, t. 1, Warszawa 2013, s. 258.

${ }^{3}$ Zob. T. Różański, Współczesna rodzina jako środowisko życia i aktywności osób starszych. Wybrane kwestie, „Teologia i Człowiek” 40 (2017) 4.

${ }^{4}$ Zob. G. Orzechowska, Rodzina wsparciem dla seniora (?), w: Rodzina wobec problemów i wyzwań współczesności. W poszukiwaniu rozwiązań, t. 2, red. B. Chrostowska, M. Dymowska, M. Zmysłowska, Olsztyn 2015.

5 A. Leszczyńska-Rejchert, Praca socjalna z seniorami w perspektywie geragogiki, Olsztyn 2016, s. 46 i 47.

${ }^{6}$ Zob. P. Białobrzewska, Przemoc wobec osób starszych - skala zjawiska, w: Społeczny wymiar życia i aktywności osób starszych, red. A. Baranowska, E. Kościńska, K.M. Wasilewska-Ostrowska, Toruń 2013; B. Szczupał, Przemoc wobec osób starszych i przemoc domowa w polskim społeczeństwie, w: Porozmawiajmy o starości..., red. B. Antoszewska, U. Bartnikowska, K. Ćwirynkało, Olsztyn 2015; E. Kramkowska, Człowiek stary jako ofiara przemocy w rodzinie, Gdańsk 2016; J.K. Wawrzyniak, Przemoc wobec osób starszych, w: A. Fabiś, J.K. Wawrzyniak, A. Chabior, Ludzka starość. Wybrane zagadnienia gerontologii społecznej, Kraków 2017. 
domowej; specyfika przemocy w rodzinie wobec ludzi starszych; zapobieganie zjawisku przemocy domowej wobec seniorów.

\section{RODZINA JAKO ŚRODOWISKO ŻYCIA CZłOWIEKA STAREGO}

Rodzina - w pedagogice rozpatrywana przede wszystkim jako środowisko wychowawcze ${ }^{7}$ - stwarza człowiekowi możliwości rozwoju oraz zaspokajania rozmaitych potrzeb w różnych fazach jego życia ${ }^{8}$. Według Agaty Chabior,

można zaryzykować tezę, że w okresie starości jej znaczenie wzrasta - opierając się na niej, człowiek starszy pozostaje osobą samodzielną i niezależną, wolną od pozarodzinnych, instytucjonalnych form wsparcia. Rodzina ułatwia seniorom proces adaptacji do starości i wszystkich zmian z nią związanych, zapewnia poczucie bezpieczeństwa9

Prawidłowe relacje i kontakty $\mathrm{w}$ rodzinie dają ludziom starszym poczucie udziału w życiu społecznym, a także sprzyjają rozwojowi ich osobowości ${ }^{10}$.

Jak już zauważono, rodzina stanowi zwykle zasadnicze środowisko aktywności życiowej seniorów. Od tego, w jaki sposób funkcjonuje, zależy nierzadko zaspokojenie rozmaitych ich potrzeb ${ }^{11}$ - nie tylko biologicznych, emocjonalnych, lecz także tych związanych np. z rekreacją, uczestnictwem w kulturze czy udziałem w życiu społecznym. Rodzina jest dla ludzi starszych często istotnym źródłem pomocy i wsparcia.

Dzieci pomagają swym starszym rodzicom zazwyczaj w wykonywaniu prac domowych, dokonywaniu zakupów, załatwianiu spraw w różnych

7 Zob. M. Łobocki, Teoria wychowania w zarysie, Kraków 2006.

8 A. Chabior, Życie rodzinne i funkcjonowanie gospodarstwa domowego, w: A. Fabiś, J.K. Wawrzyniak, A. Chabior, Ludzka starość. Wybrane zagadnienia gerontologii społecznej, Kraków 2017, s. 134.

9 Tamże, s. 135.

10 A. Leszczyńska-Rejchert, Praca socjalna z seniorami, s. 46.

11 Por. G. Orzechowska, Aktualne problemy gerontologii społecznej, Olsztyn 1999, s. 31-32; A. Leszczyńska-Rejchert, Człowiek starszy i jego wspomaganie - w stronę pedagogiki starości, Olsztyn 2005, s. 89-90. 
instytucjach ${ }^{12}$, opiekują się nimi w czasie choroby oraz świadczą pomoc $\mathrm{w}$ czynnościach pielęgnacyjnych ${ }^{13}$. W rodzinie seniorzy mogą liczyć też na wsparcie emocjonalne i duchowe ${ }^{14}$, niezwykle ważne zwłaszcza w trudnych sytuacjach życiowych (np. strata bliskiej osoby, choroba). Grażyna Orzechowska podaje, że:

Pomoc osobie starszej może charakteryzować się różnym nasileniem: od jej nadmiaru (tzw. nadopiekuńczość) przez zrównoważoną opiekę po niedobór działań wspierających. Oczywiście ta zrównoważona, proporcjonalna do potrzeb seniora jest formą najkorzystniejszą, jednakże rodzina nie zawsze jest $\mathrm{w}$ stanie sprostać takim obowiązkom ${ }^{15}$.

Bez względu na to, rodzinne wsparcie wobec różnorakich potrzeb ludzi starszych jest niezwykle istotne, potrzebne i ze względu na specyfikę tego środowiska trudne do zastąpienia ${ }^{16}$.

Osoby starsze odgrywają w rodzinie wiele ważnych ról, realizują w niej rozmaite zadania. Zaspokajają potrzeby jej członków (w tym potrzeby emocjonalne), uczą szacunku, pomagają w różnych sytuacjach ${ }^{17}$, $\mathrm{np}$. w prowadzeniu gospodarstwa domowego, opiece nad wnukami ${ }^{18}$; dzielą się wiedzą i umiejętnościami, z których korzystają inni członkowie rodziny ${ }^{19}$. Wśród zasadniczych ról rodzinnych seniorów wyróżnia się: rolę małżonka, rodzica, babci/dziadka, a niekiedy też opiekuna własnych - sędziwych rodziców ${ }^{20}$.

12 A. Chabior, Życie rodzinne, s. 138.

${ }^{13}$ D. Krzysztofiak, Oblicza starości w perspektywie lokalnej. Studium socjopedagogiczne, Kraków 2016, s. 110.

${ }^{14}$ Por. S. Kawula, Pedagogika społeczna dzisiaj i jutro, Toruń 2012, s. 153 i 154.

15 G. Orzechowska, Rodzina wsparciem, s. 63.

16 Tamże, s. 63.

${ }_{17}$ M. Duda, Rola osoby starszej w rodzinie. Wybrane zagadnienia, w: W poszukiwaniu jakości życia współczesnej rodziny polskiej, red. G. Makiełło-Jarża, Kraków 2009, s. $127-128$.

18 A. Chabior, Życie rodzinne, s. 138.

${ }_{19}$ M. Kotomska, Rodzina a osoby starsze, w: Encyklopedia starości, starzenia się i niepetnosprawności, t. 3, red. A.A. Zych, Katowice 2017, s. 223.

${ }_{20}$ B. Szatur-Jaworska, Ludzie starzy i starość w polityce społecznej, Warszawa 2000, s. 52 . 
Bez wątpienia do najistotniejszych ról społecznych ludzi starych należą role babci i dziadka ${ }^{21}$. Sposób ich realizacji jest zróżnicowany środowiskowo i zmienia się w zależności od etapu biografii osoby starszej. Wśród czynników, które różnicują pełnienie tych ról, wymienia się m.in.: stan zdrowia, miejsce stałego zamieszkania, sytuację rodzinną, poziom wykształcenia, wiek wnuków ${ }^{22}$. Babcie i dziadkowie często nie tylko sprawują opiekę nad najmłodszymi członkami rodziny, ale także uczestniczą (niekiedy w sposób znaczący) w procesie ich wychowania ${ }^{23}$. Przekazują oni młodemu pokoleniu tradycje, wartości, uczą historii, wpajają reguły postępowania. Nierzadko też wprowadzają wnuki w świat wiary, uczą modlitwy ${ }^{24}$. Ich zachowanie stanowi dla dzieci istotne źródło „informacji o sposobach postępowania w różnych sytuacjach. To one w znacznej mierze wyznaczają dziecięcą koncepcję rodziny oraz wizję własnych, przyszłych ról społecznych - małżonka i rodzica"25.

Rodzina - podlegając współcześnie dynamicznym przeobrażeniom ${ }^{26}$ - może stanowić dla jej najstarszych członków przestrzeń dla wszechstronnego rozwoju, ale niekiedy też źródło rozmaitych problemów. Zalicza się do nich m.in.: trudności finansowe, konflikty rodzinne, nadmierną opiekę nad seniorami w rodzinie czy wreszcie przemoc wewnątrzrodzinnąa ${ }^{27}$.

${ }^{21}$ Z. Szarota, Starzenie się i starość $w$ wymiarze instytucjonalnego wsparcia na przykładzie Krakowa, Kraków 2010, s. 109.

22 B. Szatur-Jaworska, Ludzie starzy i starość, s. 53.

${ }^{23}$ Zob. L. Dyczewski, Ludzie starzy i starość w społeczeństwie i kulturze, Lublin 1994.

${ }^{24}$ N. Pikuła, Etos starości w aspekcie społecznym. Gerontologia dla pracowników socjalnych, Kraków 2011, s. 104.

${ }^{25}$ U. Kempińska, Rola seniorów w rodzinie, „Pedagogika Społeczna” 58 (2015) 4, s. 85 .

${ }^{26}$ Zob. T. Różański, Z problematyki przemian i zagrożeń współczesnej rodziny, „Teologia i Człowiek” 32 (2015) 4.

27 Por. A. Leszczyńska-Rejchert, Praca socjalna z seniorami, s. 47-51. 


\section{ZAGADNIENIE PRZEMOCY W RODZINIE}

Sposób, w jaki postrzegane jest zjawisko przemocy, ściśle wiąże się z procesem przemian społecznych ${ }^{28}$. Według Cezarego Kurkowskiego: „Pojęcie to [...] w każdych warunkach będzie deklaracją praw człowieka obowiązujących w danej kulturze, kraju czy społeczeństwie. Szczególnej wartości nabiera jednak w procesie demokratyzacji życia, którego fundamentalnym przejawem jest prawo do nietykalności osobistej" ${ }^{29}$. Obecnie przemoc zalicza się do największych zagrożeń życia społecznego, nie tylko z uwagi na jej konsekwencje, ale również dlatego, że stanowi ona zjawisko dynamiczne, które nasila się ${ }^{30}$.

Najczęściej przyjmuje się, że przemoc to „każdy akt godzący w osobistą wolność jednostki, zmuszanie jej do zachowań niezgodnych z jej własną wolą" ${ }^{31}$. W literaturze psychologicznej podkreśla się potrzebę odróżnienia pojęcia przemocy od pojęcia agresji. Celem tej pierwszej jest wywarcie pewnego wpływu, podporządkowanie, z kolei drugiej - zaszkodzenie ofierze. Przemoc, pociągając za sobą czyjeś cierpienie, szkodę, stanowi sposób wymuszania zachowań, realizowania własnych potrzeb, natomiast w przypadku agresji zaszkodzenie czy wywołanie cierpienia jest jednym z zasadniczych celów ${ }^{32}$. O wystąpieniu przemocy przesądzają trzy poniższe warunki: po pierwsze, sprawca pozwala sobie na nią, ponieważ czuje się bezkarny; po drugie, jego zachowanie narusza dobro i prawa ofiary; po trzecie, zachowania te służą zaspokajaniu potrzeb sprawcy, a nie ofiary. Zazwyczaj mówi się o czterech zasadniczych formach przemocy: fizycznej, psychicznej (bądź emocjonalnej), seksualnej oraz zaniedbaniu ${ }^{33}$. Zdaniem Ireny Pospiszyl, „jest to rozróżnienie wyłącznie porządkujące,

${ }^{28}$ C. Kurkowski, Przemoc $w$ rodzinie na tle innych rodzajów przemocy, w: Encyklopedia pedagogiczna XXI wieku, t. IV, red. T. Pilch, Warszawa 2005, s. 1054.

29 Tamże, s. 1054-1055.

30 S.P. Zakrzewski, Zjawiska patologii społecznej. Przyczyny - przebieg - skutki, Poznań 2012, s. 122.

31 C. Kurkowski, Przemoc $w$ rodzinie, s. 1055.

32 E. Jarosz, Przemoc wewnątrzrodzinna, w: Elementarne pojęcia pedagogiki społecznej i pracy socjalnej, red. D. Lalak, T. Pilch, Warszawa 1999, s. 220.

${ }_{33}$ I. Pospiszyl, Przemoc $w$ rodzinie, w: Resocjalizacja. Teoria i praktyka pedagogiczna, t. 2, red. B. Urban, J.M. Stanik, Warszawa 2008, s. 57 i 58. 
ponieważ w rzeczywistości najczęściej mamy do czynienia z łączeniem różnych form przemocy"34.

Przemoc $\mathrm{w}$ rodzinie (określana też przemocą wewnątrzrodzinną bądź domową) to pojęcie, jakie dotyczy każdego rodzaju przemocy stosowanego w obrębie danej rodziny. Ten rodzaj przemocy odnosi się do małżonków, rodziców, dzieci, rodzeństwa ${ }^{35}$. Przemoc w rodzinie może być zatem wielokierunkowa ${ }^{36}$.

Jak podaje Ewa Jarosz, przemoc wewnątrzrodzinna to wszelkiego rodzaju zachowania polegające na złym traktowaniu członków rodziny, przede wszystkim w sytuacji, gdy nie mogą oni skutecznie się bronić, wszelkiego rodzaju działania aktywne i pasywne, jakie godzą w osobistą wolność człowieka i prowadzą do jego szkody psychicznej bądź fizycznej, pozostające $\mathrm{w}$ sprzeczności ze społecznymi normami oraz standardami wzajemnych relacji występujących w rodzinie ${ }^{37}$. Przemocy domowej przypisywane są następujące cechy:

- jest ona intencjonalna (stanowi zamierzone, celowe działanie człowieka, które jest wymierzone przeciw drugiej osobie);

- jest ukierunkowana na kontrolę oraz podporządkowanie drugiego człowieka;

- dokonuje się w warunkach wyraźnego braku równowagi sił (sprawca ma przewagę nad ofiarą, np. fizyczną);

- prowadzi do naruszenia elementarnych praw jednostki;

- wywołuje cierpienie, a także jest zagrożeniem dla zdrowia bądź życia ofiary ${ }^{38}$.

Objawy przemocy wewnątrzrodzinnej dostrzega się przede wszystkim w trzech sferach:

- fizycznej (np. sińce, obrzęki twarzy, rany i blizny występujące na ciele);

- emocjonalnej (np. wzrost napięcia emocjonalnego, wzmożona czujność, popadanie w skrajne nastroje);

34 Tamże, s. 58.

35 A.A. Zych, Leksykon gerontologii, Kraków 2010, s. 140.

${ }^{36}$ Por. T. Szlendak, Socjologia rodziny. Ewolucja, historia, zróżnicowanie, Warszawa 2010, s. 274.

37 E. Jarosz, Przemoc wewnątrzrodzinna, s. 220.

${ }^{38}$ S. Zakrzewski, Zjawiska patologii społecznej, s. 124. 
- społecznej (np. nieufność lub wrogość wobec innych ludzi, trudności w nawiązywaniu i podtrzymywaniu kontaktów społecznych) $)^{39}$.

Konsekwencje przemocy w rodzinie mogą obejmować zarówno następstwa bezpośrednie, jak i długotrwałe (odległe), i odnosić się do różnych sfer życia człowieka, np. fizyczno-zdrowotnej, psychicznej ${ }^{40}$. Co więcej, skutki

doznawania przemocy rodzinnej wykraczają poza zdrowie i szczęście jednostek jej doświadczających, mając reperkusje w wymiarze ponadindywidualnym - osłabiając dobrostan społeczeństwa. Przemoc wywołując liczne negatywne następstwa u ofiar, upośledza ich [...] funkcjonowanie w społeczeństwie i świecie ${ }^{41}$.

Przemoc domowa - jako zjawisko wielowymiarowe - „wymaga indywidualnego, interdyscyplinarnego podejścia do członków rodzin, ich problemów, potrzeb i zachowań oraz sytuacji, w jakiej się znajdują"42. Występowanie tego zjawiska warunkowane jest różnorakimi czynnikami - społecznymi, kulturowymi, ekonomicznymi, psychologicznymi, a także sytuacyjnymi ${ }^{43}$. Może być ono rozpatrywane $\mathrm{z}$ różnych perspektyw, np. społecznej, psychologicznej, prawnejej.

\section{SENIORZY JAKO OFIARY PRZEMOCY DOMOWEJ}

Przemoc wobec ludzi w starszym wieku oznacza „pojedynczy lub powtarzający się akt bądź brak odpowiednich działań występujący w relacji zaufania, powodujący krzywdę oraz cierpienie osób starszych"45.

39 Tamże, s. 124-125.

${ }^{40}$ E. Jarosz, Przemoc $w$ rodzinie - analiza zjawiska, w: Encyklopedia pedagogiczna XXI wieku, t. IV, red. T. Pilch, Warszawa 2005, s. 1069.

${ }^{41}$ Tamże, s. 1069.

42 B. Szczupał, Przemoc wobec osób starszych, s. 107.

${ }^{43}$ E. Jarosz, Przemoc wewnątrzrodzinna, s. 221.

${ }^{44}$ J. Surzykiewicz, Przemoc $w$ rodzinie, w: Wychowanie do życia $w$ rodzinie. Słownik pojęć, red. K. Ostrowska, Kraków 2004, s. 97.

${ }^{45}$ M. Halicka, A. Szafranek, Przemoc wobec osób starych, w: Encyklopedia starości, starzenia się i niepetnosprawności, t. 3, red. A.A. Zych, Katowice 2017, s. 149. 
Określa się ją również „jako umyślne i celowe złe traktowanie osób starszych, przejawiające się pod postacią nadużyć i zaniedbań, podejmowane przez opiekunów i/lub inne osoby pozostające w relacji zaufania" ${ }^{\prime 6}$. Złe traktowanie ludzi w wieku senioralnym może obejmować też zaniechania, np. niezaspokajanie przez opiekunów określonych potrzeb osób starych ${ }^{47}$. Jak pisze Agnieszka M. Nowak:

Populacja ludzi starszych jest szczególnie podatna na wszelkie formy przemocy. Seniorzy, słabsi fizycznie i niepracujący, stają się coraz bardziej zależni od swoich bliskich i otoczenia. Stopniowo rezygnują z wykonywanych dotychczas czynności, rozstają się ze swoimi przyjaciółmi i znajomymi, izolują się od społeczeństwa. Stosowanie przemocy wobec osób w podeszłym wieku jest sytuacją nieprzypadkową, podczas której senior doznaje szeregu urazów ze strony sprawcy ${ }^{48}$.

Czynniki ryzyka związane z występowaniem przemocy wobec osób w wieku senioralnym można rozpatrywać na czterech poziomach:

- poziomie jednostkowym (czynniki o charakterze indywidualnym);

- poziomie związku (czynniki związane z najbliższymi relacjami społecznymi, np. z członkami rodziny, partnerami);

- poziomie mikrospołecznym (czynniki związane z relacjami występującymi w bliskim środowisku społecznym, np. w kręgu sąsiedzkim, zakładzie pracy);

- poziomie makrospołecznym (uwzględniającym np. wpływ płci, pochodzenia czy norm kulturowych - jako czynników, które mogą przyczyniać się do powstawania napięć pomiędzy różnymi grupami) ${ }^{49}$.

Dwoma zasadniczymi rodzajami instytucji, w których najczęściej stosowana jest przemoc wobec przedstawicieli starszego pokolenia, są instytucje opieki oraz rodzina ${ }^{50}$. Zdaniem Beaty Tobiasz-Adamczyk:

46 Tamże, s. 149.

47 Tamże.

48 A.M. Nowak, „Wesołe jest życie staruszka...” - nie dla każdego. Przemoc stosowana wobec seniorów, w: Zagrożenia w starości i na jej przedpolu, red. M. Halicka, J. Halicki, K. Czykier, Białystok 2010, s. 358.

${ }^{49}$ M. Halicka, A. Szafranek, Przemoc wobec osób starych, s. 150.

${ }^{50}$ B. Tobiasz-Adamczyk, Przemoc w rodzinie wobec osób starszych, w: Przemoc 
Natężenie oraz rozpoznawanie zjawiska przemocy wobec osób starszych, $\mathrm{w}$ tym także $\mathrm{w}$ rodzinie zależy od sprawności funkcjonowania systemu kontroli społecznej [...] oraz mechanizmów społeczno-materialnych (instytucje społeczne) kontrolujących wymagane w danej kulturze zachowania. W zależności od sposobu funkcjonowania systemu kontroli społecznej zjawisko przemocy wobec osób starszych może być rozpoznane w różnym stopniu lub całkowicie nierozpoznane. Stąd olbrzymia rola wszystkich instytucji sprawujących opiekę nad osobami starszymi, których przedstawiciele mają szansę "wychwycenia" przypadków przemocy i skutecznego przeciwdziałania złemu traktowaniu osób starszych ${ }^{51}$.

Jak pokazują wyniki badań i analiz, ludzie starsi często stają się właśnie ofiarami przemocy ze strony członków swoich rodzin. Seniorzy, z uwagi na zły stan swego zdrowia, ograniczoną samodzielność czy niekorzystną sytuację materialną, nierzadko uzależnieni są od opieki własnych dzieci $^{52}$. Te natomiast, wykorzystując niejednokrotnie bezbronność swoich starszych rodziców, „dopuszczają się wobec nich zachowań agresywnych. Zachowanie członków rodzin wyjaśniane bywa stresem, napięciem oraz przemęczeniem związanym z opieką nad ludźmi starymi. Nadużycia i zaniedbania mogą być także wynikiem międzypokoleniowej transmisji wzorów zachowań. Częściej przemocy dopuszczają się ci, wobec których przemoc była stosowana"53. Do czynników, które zwiększają ryzyko pojawienia się przemocy wobec ludzi starych w rodzinach, można zaliczyć również: zaburzone więzi, sytuacje konfliktowe, uzależnienia, niski status społeczny osób w wieku senioralnym ${ }^{54}$. Specyfika sytuacji przemocowych w rodzinie z udziałem osób starszych zależy w dużej mierze od rodzaju samej relacji, tzn. od tego, czy jest to relacja małżeńska, rodzicielska itd. ${ }^{55}$.

w rodzinie wobec osób starszych i niepełnosprawnych. Poradnik dla pracowników pierwszego kontaktu, red. D. Jaszczak-Kuźmińska, K. Michalska, Warszawa 2010, s. 40.

${ }^{51}$ Tamże, s. 40.

${ }^{52}$ M. Halicka, K. Czykier, A. Sidorczuk, Środowiskowe uwarunkowania nadużyć i zaniedbań wobec osób starszych, w: Zagrożenia w starości i na jej przedpolu, red. M. Halicka, J. Halicki, K. Czykier, Białystok 2010, s. 340.

53 Tamże, s. 340.

54 Tamże, s. 340.

${ }_{55}$ E. Kramkowska, Człowiek stary jako ofiara przemocy, s. 94. 
Przemoc wobec seniorów w rodzinach może przyjmować rozmaite formy. Wyróżnia się wśród nich:

- przemoc fizyczną (celowe stosowanie siły fizycznej, zadawanie bólu fizycznego, np. szarpanie, bicie, kopanie, duszenie);

- przemoc psychiczną (działania mające na celu np. poniżanie, zastraszanie, ośmieszanie, szantażowanie);

- przemoc materialną/ekonomiczną (np. ograniczanie dostępu do pieniędzy, niszczenie własności osoby starszej);

- przemoc seksualną (zmuszanie do wszelkiego typu zachowań o charakterze seksualnym);

- zaniedbanie (powstrzymywanie się od opieki oraz zaspokajania potrzeb człowieka starszego, np. odmowa dostarczania pożywienia, lekarstw, ale także okazywanie obojętności czy chłodu emocjonalnego $)^{56}$.

Należy podkreślić za B. Tobiasz-Adamczyk, że: „Przemoc w rodzinie wobec osób starszych, podobnie jak przemoc wobec innych członków rodziny, rzadko występuje w jednej formie. Zwykle formy zachodzą na siebie lub pozostają ze sobą $\mathrm{w}$ ścisłej relacji”"57.

Wyniki zrealizowanych w ostatnich kilkunastu latach badań (m.in. w ramach projektu PolSenior) pokazują, że przemoc wobec ludzi starych występuje także w Polsce i nie jest to zjawisko rzadkie. Ofiarami różnych form przemocy są częściej kobiety niż mężczyźni ${ }^{58}$. Seniorzy najczęściej doświadczają przemocy we własnych rodzinach ${ }^{59}$. Zazwyczaj dotyka ich przemoc psychiczna i ekonomiczna (np. ośmieszanie, obrażanie, zabieranie pieniędzy), natomiast rzadziej - przemoc fizyczna i seksualna ${ }^{60}$. Z badań i analiz przeprowadzonych przez G. Orzechowską wynika, że wraz z wiekiem zwiększa się ryzyko wystąpienia przemocy wobec człowieka starego. Głównymi przyczynami przemocy wobec seniorów w rodzinie są problemy natury ekonomicznej oraz alkoholizm jej członków. Co więcej,

56 B. Szczupal, Przemoc wobec osób starszych, s. 108-109.

57 B. Tobiasz-Adamczyk, Przemoc $w$ rodzinie, s. 47.

58 E. Kramkowska, Człowiek stary jako ofiara przemocy, s. 112-127.

59 Tamże, s. 94.

${ }^{60} \mathrm{~J}$. Kliszcz, Psychologia potrzeb osób starszych. Potrzeby psychospołeczne po 65. roku życia, Warszawa 2019, s. 119. 
ludzie starsi nie zawsze zdają sobie sprawę z tego, że są ofiarami przemocy, często kierują się stereotypami i zwykle uważają, że problemy tego typu należy rozwiązywać w obrębie rodziny. Rzadko więc poszukują pomocy poza własnym kręgiem rodzinnym ${ }^{61}$.

Jednym z powodów niezgłaszania przemocy domowej przez seniorów jest ich zależność od samych sprawców (tj. członków rodziny). Do innych przyczyn zalicza się m.in.: strach przed nasileniem przemocy (gdyby ofiara ujawniła przemoc domową), poczucie wstydu (np. przed znajomymi), wiarę w poprawę stosunków rodzinnych, ograniczone zaufanie do instytucji zajmujących się ofiarami przemocy, brak wiedzy na temat instytucjonalnych form pomocy skierowanych do osób doświadczających przemocy $^{62}$. Jak utrzymuje Anna Leszczyńska-Rejchert:

Trudno jest ustalić rzeczywisty odsetek ludzi starszych dotkniętych przemocą w rodzinie, gdyż rzadko przebywają oni poza domem i niechętnie mówią o swoich bolesnych doświadczeniach. Wynika to ze wstydu związanego z obarczaniem się winą za złe wychowanie dzieci, z lęku przed skutkiem ujawnienia przemocy (tj. utratą opiekuna lub zamieszkaniem w placówce). Ludzie starsi są często uzależnieni od opieki swoich dzieci (ze względu na stan zdrowia, sytuację finansową), co powoduje, że stają się w obliczu przemocy całkiem bezbronni ${ }^{63}$.

Przemoc stosowana wobec seniorów może prowadzić zatem do obniżenia jakości ich życia. Niekiedy pociąga za sobą poważne konsekwencje w sferze emocjonalnej (np. fobie, lęki, depresje). Skutki dłużej trwającej przemocy mogą utrzymywać się nawet przez wiele lat ${ }^{64}$. Bez względu na to, czy przemoc w rodzinie przyjmuje „formę aktywną, czy pasywną, powoduje «okaleczenie» ofiary, które uniemożliwia jej prawidłowe uczestniczenie w życiu rodzinnym i społecznym" ${ }^{\text {"5 }}$. Następstwem tego stanu rzeczy jest nierzadko społeczne wykluczenie osób w starszym

${ }^{61}$ G. Orzechowska, Rodzina wsparciem, s. 67-68.

${ }^{62}$ B. Tobiasz-Adamczyk, Przemoc $w$ rodzinie, s. 59-60.

${ }^{63}$ A. Leszczyńska-Rejchert, Praca socjalna z seniorami, s. 50-51.

${ }^{64}$ J.K. Wawrzyniak, Przemoc wobec osób starszych, s. 325.

${ }_{65}$ M. Kondracka-Szala, Wsparcie społeczne osób stygmatyzowanych. Wirtualne grupy samopomocowe, Warszawa 2015, s. 78-79. 
wieku - rozumiane przede wszystkim w kategoriach rozpadu więzi społecznych ${ }^{66}$.

\section{UWAGI KOŃCOWE}

Rodzina, jak już podkreślano, to często główne środowisko życia i aktywności ludzi w starszym wieku. Stanowi dla nich ważne, nierzadko trudne do zastąpienia źródło wsparcia w różnych obszarach. Może być dla nich też źródłem rozmaitych problemów i zagrożeń, do których zalicza się przemoc domową. Problem ten pociąga za sobą potrzebę podejmowania zróżnicowanych działań nie tylko w zakresie pomocy społecznej ${ }^{67}$, ale także w sferze szeroko rozumianej edukacji i profilaktyki.

Zdaniem Jerzego Halickiego i Emilii Zajkowskiej: „Istotnym postulatem działań prewencyjnych jest doskonalenie współpracy przedstawicieli różnych służb oraz instytucji (tj. ośrodków pomocy społecznej, policji, służby zdrowia, wymiaru sprawiedliwości itp.), których jednym z zadań jest rozwiązywanie problemów związanych z przemocą wobec osób starszych" ${ }^{68}$. Działania profilaktyczne powinny być realizowane na różnych poziomach - indywidualnym, międzyludzkim, na poziomie społeczności i wreszcie na poziomie ogólnospołecznym ${ }^{69}$. Należy w tym obszarze wskazać na potrzebę m.in.:

- wprowadzania zmian w zakresie kształcenia służb społecznych, które zajmują się interwencjami w sytuacjach występowania przemocy (w celu budowania sprawnego systemu ochrony osób starszych);

- podejmowania odpowiednich działań resocjalizacyjnych i wy-

${ }^{66}$ Por. B. Smolińska-Theiss, Dylematy marginalizacji z perspektywy pedagogiki społecznej, w: Skazani na wykluczenie, red. M. Orłowska, Warszawa 2005, s. 54.

67 Zob. J. Cichla, Formy pomocy ofiarom przemocy $w$ rodzinie $w$ kontekście teorii $i$ doświadczeń praktycznych, w: Wybrane aspekty przemocy. Diagnoza i profilaktyka, red. R.M. Ilnicka, J. Cichla, Toruń 2009; P. Białobrzewska, Przemoc wobec osób starszych.

${ }^{68}$ J. Halicki, E. Zajkowska, Przemoc wobec ludzi starszych na przykładzie analizy akt sądowych, w: Rodzina wobec problemów i wyzwań współczesności. W poszukiwaniu rozwiązań, t. 2, red. B. Chrostowska, M. Dymowska, M. Zmysłowska, Olsztyn 2015, s. 140.

${ }^{69}$ J.K. Wawrzyniak, Przemoc wobec osób starszych, s. 328. 
chowawczych, skierowanych zarówno do seniorów (np. treningi asertywności, uczenie samoobrony), jak i do ich rodzin bądź opiekunów (np. przygotowanie do opieki nad osobą starszą, zapoznawanie $\mathrm{z}$ technikami radzenia sobie ze stresem);

- konstruowania programów pomocy i wsparcia, które będą sprzyjały eliminowaniu przemocy z życia rodzinnego i społecznego;

- przygotowania poradników dla seniorów i ich opiekunów dotyczących problemu zapobiegania przemocy wobec ludzi starszych;

- zwracania uwagi szerszej społeczności na potrzeby i problemy ludzi starszych w środowisku ich zamieszkania;

- rozwijania działalności organizacji pozarządowych w zakresie profilaktyki przemocy wobec osób w starszym wieku ${ }^{70}$.

Ważnym zadaniem edukacyjnym w kontekście profilaktyki przemocy wobec seniorów (również w rodzinie) jest podejmowanie działań mających na celu eliminowanie krzywdzących stereotypów dotyczących człowieka starego i okresu późnej dorosłości. Konieczne jest także upowszechnianie rzetelnej wiedzy na temat zjawiska przemocy (m.in. jej przyczyn, form, objawów). Istotną rolę w tym zakresie powinny odgrywać nie tylko instytucje edukacyjne i kulturalne, ale również środki masowego przekazu.

Poruszony $\mathrm{w}$ niniejszym artykule problem wymaga prowadzenia dalszych badań, a także konstruowania teorii naukowych, które wyjaśniałyby przyczyny występowania przemocy ${ }^{71}$, a w konsekwencji ułatwiały skuteczne zapobieganie temu zjawisku. Jak stwierdza Adam A. Zych, „teorie [te - przyp. aut.] mogą służyć zarówno działaniom państwa, jak i nowym rozwiązaniom prawnym, określającym zasady postępowania w przypadkach naruszania praw ludzi starszych"72.

70 A.A. Zych, Przeciwdziałanie przemocy wobec osób starszych: propozycja modelowego rozwiązania, w: Starość. Jej ciemność, jej światłość..., red. A.A. Zych, Lublin 2017, „Konteksty Społeczne” t. 5, 9 (2017) 1, s. 40-41.

71 Tamże, s. 43.

72 Tamże. 


\section{BIBLIOGRAFIA}

Adamski F., Rodzina, w: Wychowanie do życia w rodzinie. Słownik pojęć, red. K. Ostrowska, Kraków 2004, s. 104-105.

Białobrzewska P., Przemoc wobec osób starszych - skala zjawiska, w: Społeczny wymiar życia i aktywności osób starszych, red. A. Baranowska, E. Kościńska, K.M. Wasilewska-Ostrowska, Toruń 2013, s. 137-152.

Chabior A., Życie rodzinne i funkcjonowanie gospodarstwa domowego, w: A. Fabiś, J.K. Wawrzyniak, A. Chabior, Ludzka starość. Wybrane zagadnienia gerontologii społecznej, Kraków 2017, s. 134-148.

Cichla J., Formy pomocy ofiarom przemocy $w$ rodzinie $w$ kontekście teorii $i$ doświadczeń praktycznych, w: Wybrane aspekty przemocy. Diagnoza i profilaktyka, red. R.M. Ilnicka, J. Cichla, Toruń 2009, s. 107-124.

Duda M., Rola osoby starszej w rodzinie. Wybrane zagadnienia, w: W poszukiwaniu jakości życia wspótczesnej rodziny polskiej, red. G. Makiełło-Jarża, Kraków 2009, s. 119-129.

Dyczewski L., Ludzie starzy i starość w społeczeństwie i kulturze, Lublin 1994.

Halicka M., Czykier K., Sidorczuk A., Środowiskowe uwarunkowania nadużyć i zaniedbań wobec osób starszych, w: Zagrożenia w starości i na jej przedpolu, red. M. Halicka, J. Halicki, K. Czykier, Białystok 2010, s. 339-346.

Halicka M., Szafranek A., Przemoc wobec osób starych, w: Encyklopedia starości, starzenia się i niepetnosprawności, t. 3, red. A.A. Zych, Katowice 2017, s. 149-153.

Halicki J., Zajkowska E., Przemoc wobec ludzi starszych na przykładzie analizy akt sadowych, w: Rodzina wobec problemów i wyzwań współczesności. W poszukiwaniu rozwiązań, t. 2, red. B. Chrostowska, M. Dymowska, M. Zmysłowska, Olsztyn 2015, s. 129-142.

Hołyst B., Zagrożenia ładu społecznego, t. 1, Warszawa 2013.

Jarosz E., Przemoc wewnątrzrodzinna, w: Elementarne pojęcia pedagogiki społecznej i pracy socjalnej, red. D. Lalak, T. Pilch, Warszawa 1999, s. 220-221.

Jarosz E., Przemoc w rodzinie - analiza zjawiska, w: Encyklopedia pedagogiczna XXI wieku, t. IV, red. T. Pilch, Warszawa 2005, s. 1062-1074.

Kawula S., Pedagogika społeczna dzisiaj i jutro, Toruń 2012.

Kempińska U., Rola seniorów w rodzinie, „Pedagogika Społeczna” 58 (2015) 4, s. 81-96.

Kliszcz J., Psychologia potrzeb osób starszych. Potrzeby psychospołeczne po 65. roku życia, Warszawa 2019.

Kondracka-Szala M., Wsparcie społeczne osób stygmatyzowanych. Wirtualne grupy samopomocowe, Warszawa 2015.

Kotomska M., Rodzina a osoby starsze, w: Encyklopedia starości, starzenia się i niepetnosprawności, t. 3, red. A.A. Zych, Katowice 2017, s. 223-224.

Kramkowska E., Człowiek stary jako ofiara przemocy w rodzinie, Gdańsk 2016.

Krzysztofiak D., Oblicza starości w perspektywie lokalnej. Studium socjopedagogiczne, Kraków 2016. 
Kurkowski C., Przemoc $w$ rodzinie na tle innych rodzajów przemocy, w: Encyklopedia pedagogiczna XXI wieku, t. IV, red. T. Pilch, Warszawa 2005, s. 1054-1062.

Leszczyńska-Rejchert A., Człowiek starszy i jego wspomaganie - w strone pedagogiki starości, Olsztyn 2005.

Leszczyńska-Rejchert A., Praca socjalna z seniorami w perspektywie geragogiki, Olsztyn 2016.

Łobocki M., Teoria wychowania w zarysie, Kraków 2006.

Nowak A.M., „Wesołe jest życie staruszka...” - nie dla każdego. Przemoc stosowana wobec seniorów, w: Zagrożenia w starości i na jej przedpolu, red. M. Halicka, J. Halicki, K. Czykier, Białystok 2010, s. 355-364.

Orzechowska G., Aktualne problemy gerontologii społecznej, Olsztyn 1999.

Orzechowska G., Rodzina wsparciem dla seniora (?), w: Rodzina wobec problemów i wyzwań wspótczesności. W poszukiwaniu rozwiązań, t. 2, red. B. Chrostowska, M. Dymowska, M. Zmysłowska, Olsztyn 2015, s. 59-70.

Pikuła N., Etos starości w aspekcie społecznym. Gerontologia dla pracowników socjalnych, Kraków 2011.

Pospiszyl I., Przemoc $w$ rodzinie, w: Resocjalizacja. Teoria i praktyka pedagogiczna, t. 2, red. B. Urban, J.M. Stanik, Warszawa 2008, s. 57-80.

Różański T., Z problematyki przemian i zagrożeń współczesnej rodziny, „Teologia i Człowiek" 32 (2015) 4, s. 129-141 (DOI: http://dx.doi.org/10.12775/TiCz. 2015.054).

Różański T., Współczesna rodzina jako środowisko życia i aktywności osób starszych. Wybrane kwestie, „Teologia i Człowiek” 40 (2017) 4, s. 225-240 (DOI: http:// dx.doi.org/10.12775/TiCz.2017.055).

Smolińska-Theiss B., Dylematy marginalizacji z perspektywy pedagogiki społecznej, w: Skazani na wykluczenie, red. M. Orłowska, Warszawa 2005, s. 47-56.

Surzykiewicz J., Przemoc $w$ rodzinie, w: Wychowanie do życia $w$ rodzinie. Słownik pojęć, red. K. Ostrowska, Kraków 2004, s. 97-99.

Szarota Z., Starzenie się i starość w wymiarze instytucjonalnego wsparcia na przykładzie Krakowa, Kraków 2010.

Szatur-Jaworska B., Ludzie starzy i starość w polityce społecznej, Warszawa 2000.

Szczupał B., Przemoc wobec osób starszych i przemoc domowa w polskim społeczeństwie, w: Porozmawiajmy o starości..., red. B. Antoszewska, U. Bartnikowska, K. Ćwirynkało, Olsztyn 2015, s. 103-137.

Szlendak T., Socjologia rodziny. Ewolucja, historia, zróżnicowanie, Warszawa 2010.

Tobiasz-Adamczyk B., Przemoc $w$ rodzinie wobec osób starszych, w: Przemoc $w$ rodzinie wobec osób starszych i niepełnosprawnych. Poradnik dla pracowników pierwszego kontaktu, red. D. Jaszczak-Kuźmińska, K. Michalska, Warszawa 2010, s. 33-67.

Wawrzyniak J.K., Przemoc wobec osób starszych, w: A. Fabiś, J.K. Wawrzyniak, A. Chabior, Ludzka starość. Wybrane zagadnienia gerontologii społecznej, Kraków 2017, s. $315-329$. 
Zakrzewski S.P., Zjawiska patologii społecznej. Przyczyny - przebieg - skutki, Poznań 2012. Zych A.A., Leksykon gerontologii, Kraków 2010.

Zych A.A., Przeciwdziałanie przemocy wobec osób starszych: propozycja modelowego rozwiązania, w: Starość. Jej ciemność, jej światłość..., red. A.A. Zych, Lublin 2017, „Konteksty Społeczne” t. 5, 9 (2017) 1, s. 38-44. 